Printed in Great Britain by

UNWIN BROTHERS LIMTTED, WOKING AND LONDON (HL 4938) 


\section{The Text of the New Testament}

\section{Its Transmission, Corruption, and} Restoration

\section{BRUCE M. METZGER}

This book supplies information concerning both the science and the art of textual criticism as applied to the New Testament. A wide variety of textual problems is discussed. Second edition 16 plates 4 figures $45 /-$ net

\section{The New Temple}

The Church in the New Testament

\section{R. J. MCKELVEY}

This is a study of one of the neglected images of the church in the New Testament. It considers the significance of the temple in the Ancient Near East, and examines the meaning of the temple concept in Jewish literature. 42/- net Oxford Theological Monographs

\section{Gregory of Nazianzus}

\section{Rhetor and Philosopher}

\section{ROSEMARY RADFORD RUETHER}

The complex tension between rhetorical and contemplative culture, between 'literature' and 'philosophy' in the life and thought of St. Gregory of Nazianzus, is here discussed in the historical context of fourth-century Christianity. 40/- net

\section{Patristic Greek Lexicon}

\section{Fascicle 5: Addenda et corrigenda}

This fascicle completes the work. The first four fascicles are still available, each 84/- net; fascicles I-V in one volume, $£ 22$ net

\section{The Ecclesiastical History of Orderic Vitalis}

Volume II, Books III and IV

Edited and translated by MARJORIE CHIBNALL

The Historia Ecclesiastica of Orderic Vitalis has been called 'the greatest social history of the Middle Ages'. This volume includes an account of the early years of the Norman monastery of St. Evroul, to which Orderic was sent as a child oblate, and a narrative of the Conquest of England and the Norman settlement up to 1075. Frontispiece 90/-net Oxford Medieval Texts

\section{Theological Science}

Based on the Hewett Lectures for 1959

\section{THOMAS F. TORRANCE}

Professor Torrance shows that theological science necessarily differs from other sciences through the uniqueness of its object, for God cannot be treated merely as a constituent of the universe. This is a philosophical investigation on the highest level. $84 /-$ net

\section{Space, Time and Incarnation}

\section{THOMAS F. TORRANCE}

Professor Torrance here seeks to articulate the rational structure of theology within the context of modern science and culture. $25 /$ - net

\section{OXFORD \\ UNIVERSITY \\ PRESS}




\section{The Bhagavad Gitā}

Translated with a Commentary based on the Original Sources by

R. C. ZAEHNER

Of the Hindu sacred books the Bhagavad Gita $\vec{a}$ is the most widely read and probably the most important for the understanding of religious mysticism. This edition tries to explain its thought from the Gitā itself and closely allied texts - the later verse Upanishads and the doctrinal portions of the Mahābhārata. $88 /-$ net

\section{The Legacy of Guilt}

\section{A Life of Thomas Kendall \\ JUDITH BINNEY}

Thomas Kendall was among the first group of lay missionaries settled in New Zealand by the Church Missionary Society in 1814. The author of this first full biography has investigated the background of Evangelical belief as well as the available historical records. 12 plates 1 map 66/-net University of Auckland Press

\section{Jonathan Edwards}

The Narrative of a Puritan Mind

EDWARD H. DAVIDSON

The biography of one of America's foremost Puritan thinkers. 57/- net Harvard University Press

\section{The Cambridge Platonists}

Edited by GERALD CRAGG

The Cambridge Platonists were a small but significant group of later seventeenthcentury thinkers. This book outlines the thought of the group and identifies its chief members. $72 /$ - net A Library of Protestant Thought OUP New York

\section{Ferdinand Christian Baur on the Writing of Church History}

Edited and translated by

PETER C. HODGSON

Baur was a great and controversial theologian. The purpose of this book is to make his work more accessible to the English-speaking world. 68/- net A Library of Protestant Thought OUP New York

\section{The Heritage of the Reformation}

\section{WILHELM PAUCK}

Dr. Pauck explores the teachings and experiences of Luther and Calvin, the spirit of the Reformation ministry and the Catholic response to the Reformation, placing these against the problems of Protestant theology today. Second edition 23/6 net Galaxy Books OUP New York

\section{The Story of the General Theological Seminary}

POWEL M. DAWLEY

The General Theological Seminary, established in 1817, was the first institution in the Anglican Communion devoted exclusively to theological education. $65 /$ - net OUP New York

\section{Schism and Renewal in Africa}

An Analysis of Six Thousand Contemporary Religious Movements

\section{DAVID B. BARRETT}

This study examines the vast number of movements of renewal, protest, and dissidence which have been taking place in Africa inside and outside the Protestant and Catholic Churches in thirty-four nations and three hundred tribes over the last hundred years. 17 plates 10 text figures 1 map 65/-net OUP East Africa

OXFORD

UNIVERSITY PRESS 


\section{The Cambridge History of the Bible}

\section{Volume 2: The West, from the Fathers to the Reformation}

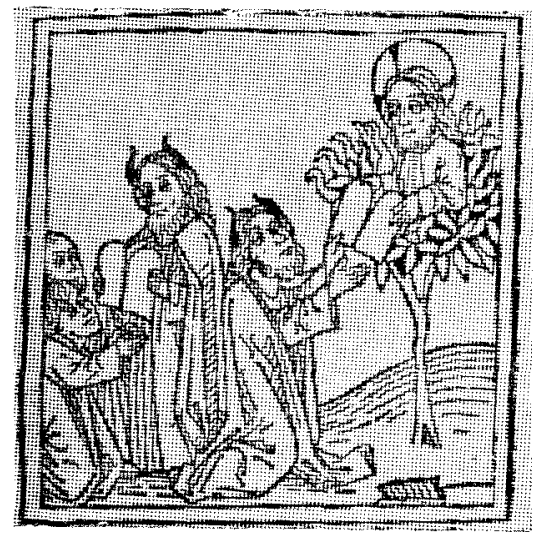

\section{Edited by G. W. H. LAMPE}

The Cambridge History of the Bible treats the Bible as the central document of Western civilisation: a source of doctrine and of Church government, and an influence on education, on the growth of scholarship, and on art and literature, as well as on the liturgy and life of the Church. This volume covers the period from Jerome and the Fathers to the time of Erasmus.

70s. net

\section{Religion in the Middle East}

\section{Two Volumes}

\section{General Editor: A. J. ARBERRY}

Subject Editors: DR. E. I. J. ROSENTHAL (Judaism)

CANON M. A. C. WARREN (Christianity)

PROFESSOR C. F. BECKINGHAM (Islam)

'Amongst the factors dividing and, to a certain extent, uniting the peoples of the Middle East, not the least interesting and noteworthy are the religions they variously profess and the sects within each religion by which they are further fragmented.'

Volume I studies Judaism and Christianity, Volume II Islam; and their relationship with each other in concord and in conflict, during the last hundred years. The contributors discuss the interaction of ethnic, economic, political, social and cultural factors to help a fuller understanding of the contemporary religious situation.

\section{CAMBRIDGE UNIVERSITY PRESS}




\section{SuBSCRIPTIONS}

Orders may be sent to any bookseller or subscription agent, or direct to Cambridge University Press, Bentley House, 200 Euston Road, London N.W.r. Subscriptions in the USA and Canada should be sent to the American branch of the Press, 32 Last 57 th Street, New York, N.Y.10022, USA. Each volume is published in two parts, appearing in October and April. The subscription price is 50 . net, including postage, in the UK ( $\$ 8.50$ in the USA). Single parts are available at 30 s. net in the UK $(\$ 4.75$ in the USA), plus postage.

Claims for non-receipt of copies will not be entertained if they are made more than four months after publication.

\section{NOTES FOR \\ CONTRIBUTORS}

1. Contributions and books for review should besent to the editor, Professor H.D. Lewis, King's College, Strand, London, W.C.2. Books published in America should be sent to Professor J. E. Smith, Department of Philosophy, Yale University, New Haven.

2. Contributions should normally be in English and should preferably be typewritten (double-spaced on quarto paper). Contributors should keep a copy themselves for use when correcting proofs.

3. Submission of an article is taken to imply that it has not previously been published, or is not being considered for publication elsewhere.

4. All contributors receive 50 free separates. 


\section{Religious Studies}

Volume 5, Number 1, October 1969

\section{CONTENTS}

RICHARD H, BELL

Wittgenstein and Descriptive Theology

PAUL WIENPAHL.

Spinoza and Wang Yang-Ming

F. MICHAEL MCLAIN

Analysis, Metaphysics and Belief

A. C. EWING

Further Thoughts on the Ontological Argument

JOHN F. MHLLER

Science and Religion: Their Logical Similarity

I. KELLENBERGER

The Falsification Challenge

ANTONY FLEW

The Falsification Response

THOMAS MCPHERSON

The Falsification Challenge: A Comment

JOHN KNOX, JR.

Can the Self Survive the Death of its Mind?

JOSEPH S. WU

Some Humanistic Characteristics of Chinese Religious Thought

Revieze article

ERROL E. HARRIS

A Return to Moral Philosophy

Reviezes

\section{CAMBRIDGE UNIVERSITY PRESS}

Bentley House, 200 Euston Road, London, N.W.1

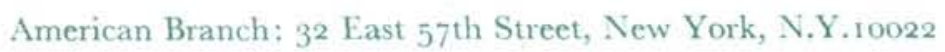

3os. net $\$ 4.75$ in U.S.A. Subscription Price 50s. net $\$ 8.50$ in U.S.A.

Religious Studies is indexed in the Index of Religious Periodical Literature 